\title{
EDUCATION IN REGIONAL ECONOMICS
}

\author{
William A. Schaffer
}

Georgia Institute of Technology

This paper is concerned with the number and content of regionrelated courses in economics now in our college curricula. The increased interest of society in the regional approach to solving current social and economic problems is clear. The last two decades have seen rapid increases in the number of programs stressing regional development and through casualobservation it is clear that the academic community has responded to the academic needs these developments have created. But what of the nature of this response? Are the techniques of regional analysis worth including in the bag of tools assembled for tomorrow's leaders? Are university curricula reflecting changes in regional policy and research interest? In which schools and at the hands of professors with which backgrounds? And how do the courses themselves reflect current interest?

In what follows, we present an outline of our survey procedures, a statistical profile of education in regional science--with an emphasis on regionaleconomics--both for the nation and the Southeast, and a discussion of various aspects of the courses themselves.

\section{$\underline{\text { Survey }} \underline{\text { Procedure }}$}

The information reported here was gathered through two surveys of regional scientists.

The first survey was conducted in the summer of 1968. A questionnaire was mailed in mid-July to members of the Regional Science Association living in the United States. Questionnaires were not mailed to Canada because of a postal strike; due to language barriers and postal expense, none were mailed to other countries. Of the approximately 1400 questionnaires mailed, 188 were returned, a response of approximately 13 percent. This low response may be partly attributed to the fact that not all members of The Regional Science Association are in the teaching profession. And of those who are, many are away for the summer working on special studies of research projects.

In retrospect, we can see several problems associated with the questions asked. One was in the definition of a "regional science" department, professor, or course. Several respondents expressed confusion on this point--many courses and professors which some would classify as related to "regional science" a re traditionally classified in a specific subdiscipline. Anotherwas in forcing the educator to recall the year in which a course was first offered, its frequency of offering, and the average number of students. Only where the educator appears intimate with (was teaching) a particular course could we rely on his response, which was typically hurried. An early conclusion of our analysis is that most professors are neither familiar with nor interested in courses offered by colleagues and other departments.

Included in our questionnaire was a request for copies of materials used by the respondent in teaching his courses, to give us insight into the current state of the art of teaching regional science. We felt that course outlines and reading lists, as well as quizzes or special class handouts, wouldindicate which topics are considered by most professors to be important in helping students approach today's regional problems. Our request 
for teaching materials drew a response of 88 outlines, or reading list-outline combinations. Of these, 68 courses seem to represent a true regional approach and have formed our sample for a review of courses across the nation.

The second survey was conducted in March and April 1970. This time we concentrated our effort on the courses associated with the economics of space and regions as offered by colleges in the Southeast. We limited our survey of the Southeast to those states contained within the bounds defined by the Southeastern Regional Science Association. Included by this definition are Maryland, West Virginia, Virginia, Kentucky, Tennessee, North and South Carolina, Georgia, Florida, Alabama, and Mississippi. A fairly extensive collection of catalagues for colleges in the Southeast was reviewed for initial coverage. We should note he re that the catalogues available were not always the most recent and that even the most recent are not always accurate records of courses actually being offered. Statements describing the course offerings of departments of economics, geography, and business we re examined for their regional content. We noted courses in the economics of location, regional or urban economics, regional science, and economic geography. Since geography departments by nature teach courses dealing with space we selected only those explicitly associated with economics. Planning departments were lightly considered for the same reason and because of their relative scarcity in the Southeast.

Given this list of colleges offering regional courses, we then attempted to interview by telephone an appropriate faculty member at each institution in order to collect information comparable to that collected earlier on the national level. While our coverage of the area has not amounted to a census, we have nevertheless gotten in touch with someone at most of the major colleges and universities listing regional economics courses in their catalogues. These interviews form the basis for our conclusions with respect to the Southeast.

\section{Characteristics of Regional Scientists and Their Institutions}

Our survey of the Regional Science Association drew replies from 188 persons. Of these respondents, 68 were employed by organizations not usually classified as teaching institutions, although an occasional response mentioned previous or possible future teaching duties, presumably in addition to the primary job. Table I shows that most of these respondents were working for government agencies. Almost 70 percent held a master's degree, with the remainder split evenly between bachelor and doctoral degrees. While a significant 60 percent graduated after 1960 , almost 25 percent graduated before 1950. The schools from which they graduated were scattered across the nation, with no one school providing more than three graduates in our sample.

Table II records the characteristics of regional scientists responding to our survey who were teaching at the time. These educators represent 106 institutions in 33 states plus the District of Columbia. Less than one fourth of these institutions a re privately supported. Over 80 percent of these respondents possess a doctorate; most degrees were in economics (42 percent), geography ( 34 percent), and regional science (6 percent). Over 70 percent of this sample graduated after 1960, with the remainder concentrated largely in the 1950's. By school, some concentration was also evident, with the University of Washington producing 10 percent of the sample, Pennsylvania 9 percent, Chicago 6 percent, and Berkeley, Harvard, Michigan, and Syracuse 5 percent each.

Thirty-three of the respondents holding teaching positions were in the 
Southeast, accounting for about 27 percent of the educator sample, and they show up as having similar characteristics to those in the rest of the nation. Most of them hold a doctoral degree, and they are gene rally young, having received their degrees in the 1960's. One difference is their specialization: fewer are geographers and more are economists. By degree, professors in the Southeast are reasonably scattered. Nine percent ( 3 respondents) of the sample graduated from each of the following: Harvard, North Carolina, Ohio State, Syracuse, and Tennessee. Michigan and West Virginia each provided 6 percent ( 2 respondents) of the sample.

TABLE I. CHARACTERISTICS OF REGIONAL SCIENTISTS EMPLOYED BY NON-EDUCATIONAL INSTITUTIONS: THE NATION

\section{Characteristic}

Types of institutions:

Degree level

Date conferred:

$\begin{array}{lc} & \text { Percent } \\ \text { Government } & 68 \\ \text { Private } & 32 \\ \text { Bachelor } & 16 \\ \text { Master } & 68 \\ \text { Ph. D. } & 16 \\ \text { Before } 1930 & - \\ 1930-1939 & 4 \\ 1940-1949 & 18 \\ 1950-1959 & 17 \\ 1960-1968 & 61\end{array}$

TABLE II. CHARACTERISTICS OF EDUCA TORS IN REGIONAL SCIENCE, 1968

Characteristic

(1) Highest academic degree

Bachelor: Economics

Master's: Economics or Business

Geog raphy

Ułban Planning

Sociology

Total Master's

Doctor: Agricultural Economics

Business Administration

Economics

Geography

Economic Geography

Operations Research

Political Science

Regional Science

Sociology

Natural Sciences (Water Resources)

Total Doctor's

(2) Date degree conferred

Before 1930

1930-1939

$1940-1949$

$1950-1959$

$1960-1968$
Percent for

$\underline{\text { Nation }}$ Southeast

\begin{tabular}{|c|c|}
\hline 1 & 3 \\
\hline 5 & 12 \\
\hline 7 & - \\
\hline 3 & - \\
\hline 1 & - \\
\hline$\overline{16}$ & $\overline{15}$ \\
\hline 4 & - \\
\hline 3 & - \\
\hline 37 & 58 \\
\hline 24 & 21 \\
\hline 3 & - \\
\hline 1 & - \\
\hline 1 & - \\
\hline 6 & - \\
\hline 3 & - \\
\hline 1 & - \\
\hline$\overline{83}$ & $\overline{79}$ \\
\hline 1 & - \\
\hline 3 & 3 \\
\hline 3 & - \\
\hline 21 & 12 \\
\hline 72 & 85 \\
\hline 100 & $\overline{100}$ \\
\hline
\end{tabular}


Table III provides information on characteristics of the institutions offering courses in regional science. Most are large universities offering courses used at all three degree levels. But 25 percent concentrate their work exclusively on the graduate level, while 18 percent teach only to undergraduates. Economics barely predominates as a department, followed closely by geography.

Schools in the Southeast generally conform to this pattern. Southern schools tend to be smaller and bear larger titles. The degree levels involving regional-science courses are roughly similar to those in the national pattern. Slightly more of the courses than would be expected are taught in economics departments.

TABLE III. PROFILE CHARACTERISTICS OF INSTITUTIONS OFFERING COURSES RELATED TO REGIONAL SCIENCE, 1968

(1) Siaracteristic

Size of institution

Less than 1,000

$1,000-4,999$

$5,000-9,999$

$10,000-19,999$

$20,000-50,000$

Over 50,000

(2) Orientation of institution

University

Liberal arts

Engineering

Teacher education

(3) Degree levels involving regional-science courses

Bachelor only

Master only

Doctor only

Bachelor and Master

Master and Doctor

Bachelor, Master, and Doctor

(4) Departments offering regional-science courses

Agricultural Economics

Economics

Geography

Planning

Sociology

Urban Affairs or Real Estate
Percent for

Nation Southeast

$\begin{array}{rr}2 & - \\ 9 & 9 \\ 24 & 26 \\ 35 & 52 \\ 28 & 13 \\ \frac{2}{100} & -\end{array}$

\begin{tabular}{rr}
78 & 92 \\
15 & 4 \\
3 & 4 \\
4 & - \\
\hline 100 & 100
\end{tabular}

$\begin{array}{rr}18 & 13 \\ 9 & - \\ 6 & - \\ 12 & 33 \\ 10 & 4 \\ \frac{45}{100} & \frac{50}{100}\end{array}$

\begin{tabular}{rr}
3 & 3 \\
36 & 47 \\
35 & 38 \\
14 & 3 \\
3 & 3 \\
9 & 6 \\
\hline 100 & 100
\end{tabular}

\section{Regional Economics in the Southeast}

The results of our survey of regional courses in the Southeast in 1970 are summarized in Table IV. They indicate economic geography to be a frequently offered course across the Southeast. The number of courses offered per state generally correlates with population, with North Carolina and Tennessee leading by number. 
TABLE IV. REGION-RELATED COURSES IN ECONOMICS AND GEOGRAPHY IN THE SOUTHEAS T, 1970

\begin{tabular}{|c|c|c|c|}
\hline \multirow[b]{2}{*}{ School } & \multicolumn{3}{|c|}{ Offering department } \\
\hline & Economics & Other & Geography \\
\hline Alabama & $\frac{9}{9}$ & & $\frac{5}{5}$ \\
\hline University of Alabama (Tuscaloosa) & 4 & & \\
\hline University of Alabama (Birmingham) & 2 & & \\
\hline University of Alabama (Huntsville) & 1 & & \\
\hline Florence State College & 1 & & \\
\hline Samford University & 1 & & \\
\hline Florida & 8 & 4 & 5 \\
\hline Florida State University & 3 & 1 & \\
\hline Florida Technological University & 1 & & \\
\hline University of Florida & 2 & 3 & \\
\hline Jacksonville University & 1 & & \\
\hline University of Miami & 1 & & \\
\hline Georgia & 7 & 4 & 16 \\
\hline Emory University & 1 & & \\
\hline Georgia Institute of Technology & 2 & & \\
\hline Georgia State University & 2 & 2 & \\
\hline University of Georgia & 2 & 2 & \\
\hline Kentucky & 4 & 1 & 18 \\
\hline University of Kentucky & 3 & & \\
\hline Murray State University & & 1 & \\
\hline Morehead State University & 1 & & \\
\hline Maryland & 4 & & 13 \\
\hline Johns Hopkins University & 1 & & \\
\hline University of Maryland & 3 & & \\
\hline Mississippi & 2 & & 7 \\
\hline Mississippi College & 1 & & \\
\hline University of Southern Mississippi & 1 & & \\
\hline North Carolina & 7 & & 28 \\
\hline Atlantic Christian University & 1 & & \\
\hline Duke University & 1 & & \\
\hline UNC (Asheville) & 1 & & \\
\hline UNC (Chapel Hill) & 3 & & \\
\hline Wake Forest University & 1 & & \\
\hline South Carolina & 5 & & 5 \\
\hline Clemson University & 2 & & \\
\hline University of South Carolina & 3 & & \\
\hline Tennessee & 14 & 2 & 22 \\
\hline East Tennessee State University & 1 & & \\
\hline King College & 1 & & \\
\hline Memphis State University & 2 & & \\
\hline Middle Tennessee State University & 2 & & \\
\hline University of the South & 1 & & \\
\hline University of Tennessee & 5 & 2 & \\
\hline Vanderbilt University & 2 & & \\
\hline Virginia & 4 & 1 & 12 \\
\hline Richmond Professional Institute & 1 & & \\
\hline Virginia Polytechnic Institute & 2 & & \\
\hline College of William and Mary & 1 & & \\
\hline West Virginia & 3 & & 8 \\
\hline West Virginia University & 3 & - & $\ldots$ \\
\hline Total & 67 & 12 & 139 \\
\hline
\end{tabular}


depend more upon special faculty skills. Not every economist is prepared to teach a regional specialty. Tennessee leads, with many courses spread throughout the state system. Alabama follows, with interests largely based on faculty holding degrees from the University of Tennessee. The courses tend to be concentrated in the universities, where graduate work and faculty versatility are the rule. The exception is Mississippi, where we found only two courses throughout the state and these at neither of the two largest schools in the state.

\section{$\underline{\text { Organization of Courses in Regional Economics }}$}

Limiting our range only to the broad outline of courses in location, regional, and urban economics, let us briefly examine several course formats. This task is difficult. Very few of the courses we reviewed are similarly organized. Some provide only one-level divisions followed by reading assignments whose titles indicate the major contents of each section; others are detailed at several levels. And none can be relied upon to use definitions comparable to those of others. As a consequence, we review these courses with up to two-level detail at the risk of slighting some respondents and confusing some readers.

Few courses identifiable as "location theory" or "the economics of location" appear to be pure. One exception is a graduate level course by Hugh Nourse (Illinois). It concentrates on location questions presented in the first part of his text ${ }^{1}$ and is organized as follows:

I. Introduction

II. Location of the individual producer

III. Systems of cities

A. Trading areas in a homogeneous plain

B. A simple model of a system of cities

C. Trading areas in more complex situations

D. Systems of cities

IV. Industrial location patterns

A. Geographic dispersion of manufacturing

B. Geographic variations in input prices

C. Orientation

D. Agglomeration economies

V. Land use

A. Rent

B. Supply a reas

C. Agricultural land use

D. Commercial and industrial land use

E. Residential land use

F. Spatial equilibrium and land-use patterns

VI. General equilibrium in location theory

Nourse extends his text material with numerous reading references. In a lower-level course, Nourse remains substantially within the confines of his text, adding the following topics to the first six listed above:

VII. Measurement of regional economic activity

VIII. Interregional theory of income and trade

IX. Regional economic growth

X. The impact of growth on regional structure

XI. Public policy

Another variation on the upper-level course, labelled "The Economics of Spatial Relations, " has been organized by Alan Winger (Kentucky) 
around Martin Beckmann's text ${ }^{2}$ as follows:

I. Space in the economic system

II. Earlier location models

III. Location of the plant

IV. Location of an industry

V. Central places

VI. Intra-urban location

VII. Equilibrium

VIII. Locational dynamics

Here Winger deemphasizes the regional structure, concentrating on more traditional location models.

A more typical senior-level course is that of Bernard McCarney (Illinois State). Called "Location Theory and Regional Analysis," this survey is outlined as follows around a series of readings:

I. Introduction

A. Definitions and purposes of regional economics

B. Scope of regional economics

II. Location theory--broad outlines

A. Von Thunen--location of agricultural activities

B. Alfred Weber--the location of a firm

C. August Lösch--the locational pattern of industries

D. Extensions and synthesis of location theory

III. Specific topics in location theory

A. Transfer costs

B. Scale economies, market and supply areas

C. Spatial differentials in cost of local inputs, and substitution

D. Competition for space

E. Labor and location

F. Agglomeration

IV. Regional economic analysis--techniques and a survey of applications

A. The economic base approach

B. Regional input-output analysis

C. Regional income accounts

While this organization provides the instructor more opportunities to create interest in continued study, it obviously pushes against some serious time constraints for a one-quarter course. Policy implications and special topics seem crowded out by a need to cover the essential economic framework.

If more time is available or if the course is cast on a less restricted graduate level, other variations a re common. John Cumberland (Maryland), for example, extends his course (Location Theory and Regional Analysis) to include other methods of analysis and concludes with a topic of personal interest, natural resource menagement and environmental quality. Koichi Mera (Harvard) intensifies his one-semester course on "Location and Regional Economics" for undergraduates and graduates to include all of the above plus policy discussions.

I. Introduction

A. Objectives of regional analysis

B. History of regional growth

C. Regional policies

D. Definition of regions

II. Theory of industrial location

A. Competition along a linear space 
B. Compa rative-cost analys is

C. Current formulations

III. Interregional trade

A. Factor and resource endowment

B. Direction of trade change over time

IV. Spatial and interregional equilibrium theory

A. Spatial competition equilibrium

B. Inter regional equilibrium

C. Central place theory

D. Interregional input-output model

V. Regional growth: theory and history

A. Factor movements

B. Regional efficiency

C. Measurement of historical growth patterns

D. Changes in the distribution over time

VI. Regional income and employment

A. Income components

B. Produced and received income

C. Cyclical fluctuations

VII. Economies of agglomeration

A. Scale economies

B. Industrial complex ana lysis

C. Urbanization economies

Other courses could be outlined. In general, our review indicates that introductory regional courses spread over a wide range, almost always starting with a review of location theory and venturing into regional economics, but usually staying within the context of traditional economics. The approach commonly depends on the text. Edgar Hoover's The Location of Economic Activity $^{3}$ is an easy text for a course such as McCarney's, allowing room for expansion.or change as desired. Nourse's Regional Economics forces a fairly broad coverage, but requires more economic sophistication. Beckmann's Location Theory, clear and concise, provides ample opportunity to use supplementarymaterial. Siebert's Regional Economic Growth ${ }^{4}$ is more specific and demands closer attention to an integrates text; it is les readily divisible.

Urbaneconomics is a more demanding topic, in the sense of requiring the instructor to be more of a political economist than an economic analyst. Throughits high density, the city intensifies problems of location, movement, and growth and clearly forces us to examine problems overlapping with those of other disciplines. Topics coveredat three schools give the tenor of these courses as currently taught. as follows:

R. L. Pfister (Indiana) organizes his "Applied Urban Economics" course

I. Introduction--regional and urban growth trends

II. Location theory

III. The theory of urban growth

IV. Urban transportation

V. Urban public economy

VI. Pollution and the urban environment

VII. Urban poverty and racial problems

VIII. Urban housing, urban renewal, and city planning

IX. The provate sector and urban development

X. Overview 
While maintaining contact with an economic base, Pfister quickly moves on to a discussion of transportation, pollution, poverty, housing, and other critical problems.

While changing the economic base of the course slightly, Hugh Knox (North Carolina) presents a similar list of topics in his "Urban Economics":

I. General equilibrium theory and urban development

II. Urban economic growth theory

III. Optimum city size and spatial patterns

IV. Urban growth and the environment

V. Urban public economy.

VI. Housing and urban renewal

VII. Urban transportation

VIII. Urban poverty and race

IX. A national urban policy

A third arrangement is that of a course presented jointly by John Mayer, John Kain, and Koichi Mera (Harvard):

I. General theoretical models

II. Simulation models of metropolitan structure

III. Intra-metropolitan industry location

IV. The determinants of residential location and the travel behavior of urban households

V, Racial problems in metropolitan a reas

VI. Urban education systems, de facto segregation, and equality of educational opportunity

VII. Costs and benefits of urban services and municipal finance VIII. Housing markets

Again, the major difference appears to be in the theoretical base of the course and perhaps in the emphasis awarded to problems. While course details and readings may differ substantially, the general outlines appear similar.

In conclusion we can simply note that regional economics is generally taught in three stages. The first takes a microeconomic approach in examining traditional location problems. The second takes a macroeconomic approach to regional economics and explores methods of regional analysis. The third tackles urban problems in an economic context. Neither the undergraduate nor the graduate curriculum in today's diversified programs in economics seems capable of expanding to permit an orderly development of these stages. Given this restriction it seems that we should make room in our introductory surveys for at least a brush with u rban problems. 


\section{FOOTNOTES}

* The research underlying this paper was supported by the Office of Economic Research, Economic Development Administration, U.S. Department of Commerce (OER-163-G-67-13). I am indebted to Mr. Charles L. Webb and Mrs. Stanlee L. Schaffer for their assistance.

${ }^{1}$ Hugh O. Nourse, Regional Economics (McGraw-Hill, 1968).

${ }^{2}$ Martin Beckmann, Location Theory (Random House, 1968).

3 Edgar M. Hoover, The Location of Economic Activity (McGraw-Hill, 1948).

${ }^{4}$ Horst Siebert, Regional Economic Growth: Theory and Policy (International Textbook Company, 1969). 